\title{
Thermal Degradation of Ligno-Cellulosic Fuels: Biopolymers Contribution
}

\author{
Valérie Leroy, Eric Leoni and Dominique Cancellieri \\ University of Corsica (SPE UMR CNRS 6134)
}

France

\section{Introduction}

Every year, thousands hectares of forest do burn in southern Europe. The Mediterranean area is especially affected during the dry season. Nevertheless, in spite of considerable efforts in fire research, our ability to predict the impact of a fire is still limited, and this is partly due to the great variability of fire behaviour in different plant communities (De Luis et al., 2005).

The combustion of forest fuels is partially governed by their thermal behaviour since this step produces a flammable gas mixture. Therefore, the analysis of the thermal degradation of lignocellulosic fuels is decisive for wildland fire modelling and fuel hazard studies (Dimitrakopoulos, 2001; Balbi et al., 2000; Stenseng et al., 2001). We propose in this work to focus on the thermal degradation of different forest fuels and their main components. Following a literature survey, we noticed that there is a lack in the description of the thermal degradation of forest fuels concerned by wildland fires (Grishin et al., 1983; Larini et al., 1998; Sero-Guillaume \& Margerit, 2002; Linn \& Cunningham, 2005). Even if these models are very different, it's well known that the energy emitted remains a crucial data. Classic approaches are based on the consideration of the low heat content value obtained by bomb calorimeter (Rothermel, 1983; Andrews, 1986; Nunez-Regueira et al., 2005). The experiments are led in constant volume what bring about a strong temperature raising, and with an excess of pure oxygen. These conditions are far from those met during a wildfire at atmospheric pressure in the air. DSC seems to be a convenient tool in order to follow the thermal degradation at the laboratory (Liodakis et al., 2002).

The degradation of forest fuels begins with the pyrolysis process from $373 \mathrm{~K}$ to $773 \mathrm{~K}$ (Simeoni et al., 2001; Shanmukharadhya \& Sudhakar, 2007; Tonbul, 2008; Yuan \& Liu, 2007). Non-combustible products, such as carbon dioxide, traces of organic compounds and water vapour, are emitted between $373 \mathrm{~K}$ and $473 \mathrm{~K}$. Above $473 \mathrm{~K}$, the pyrolysis breaks down the fuels components into low molecular mass gases (volatiles), and carbonaceous char. Around $773 \mathrm{~K}$ all the volatiles are gone; the remaining char is oxidized in a glowing combustion (Beall \& Eickner, 1970).

Wood is a complex organic material, composed of cellulose ( 40 to $45 \%$ for coniferous trees and 38 to $50 \%$ for leafy trees), lignin (26 to $34 \%$ for coniferous trees and 23 to $30 \%$ for leafy trees), hemicellulose (7 to $15 \%$ for coniferous trees and 19 to $26 \%$ for leafy trees), extractives $(<15 \%)$, ashes $(<1 \%)$ water and mineral matter (Orfao et al., 1999; Weiland et al., 1998). The chemical composition varies from species to species and within the same variety it varies with the botanical origin, age and location in the tree (trunk, branches, crown and roots). In 
general, previous works refer to different commercial biopolymers (cellulose, xylan to represent hemicellulose...) whose structure is quite different from the native one (Koufopanos et al., 1989; Kohler et al., 2005; Alen et al., 1996; Cozzani et al., 1997). To have a realistic representation of biopolymer behaviour, it is essential to extract it directly from its source and to perform the analysis on the extracted matter.

Similarly to other authors (Koufopanos et al., 1989; Kohler et al., 2005; Miller \& Bellan, 1997; Caballero et al., 1996), we made the assumption that the principal components of the fuel contributes to the thermal behaviour of the whole fuel itself and we showed in the present work that the enthalpy reaction of the thermal degradation follows this law.

The aim of this work was to quantify the participation of the principal components of the fuel to the reaction enthalpy of thermal degradation of the fuel. In a first time we have developed and used an analytical procedure in order to determine the content of each component in the forest fuels. In a second time, we have used DSC to record the enthalpy of the thermal degradation of the fuels and their components (previously extracted) under air sweeping. Then, calculated reaction enthalpy and experimental ones are compared.

\section{Material and methods}

\subsection{Vegetal samples}

We chose to study the thermal degradation of rockrose (Cistus monspeliensis: $\mathrm{CM}$ ), heather (Erica arborea: EA), strawberry tree (Arbutus unedo: AU) and pine (Pinus pinaster: PP) which are representative species of the Corsican vegetation concerned by wildland fires. Naturally, the methodology developed hereafter is applicable to every lignocellulosic fuel.

Plant materials were collected from a natural Mediterranean ecosystem situated away from urban areas in order to prevent any pollution on the samples. Small particles $(<6 \mathrm{~mm})$ are considered in governing the dynamic of fire spread (Morvan \& Dupuy, 2004; Burrows, 2001; Morvan, 2005). So we sampled the foliage and aerial parts of previously cited species. For each species, a bulk sample from six individual plants was collected in order to minimize interspecies differences. Current year, mature leaves were selected, excluding newly developed tissues at the top of the twigs. About $500 \mathrm{~g}$ of each species were brought to the laboratory, washed with deionised water and oven-dried for 12 hours at 333K (Leoni et al., 2003). Dry samples were then grounded and sieved to pass through a $600 \mu \mathrm{m}$ mesh, then kept to the desiccator. The sieved powdery sample was stored in airtight plastic containers for future use. All the analysis (chemical and thermal) were performed on these powders. The moisture content coming from self-rehydration was about $4 \%$ four percent for all the samples before the analysis.

The elemental analysis was carried out at the SCA (Service Central d'Analyse) USR 59 CNRS, and the results are shown in Table 1.

\begin{tabular}{lcccc}
\hline & $\begin{array}{c}\text { Carbon } \\
(\%)\end{array}$ & Hydrogen (\%) & Oxygen (\%) & N, mineral matter (\%) \\
\hline AU & 48.24 & 6.15 & 40.33 & 5.28 \\
EA & 52.43 & 6.98 & 35.92 & 4.63 \\
CM & 46.58 & 6.22 & 37.68 & 9.52 \\
PP & 50.64 & 6.76 & 41.53 & 1.70 \\
\hline
\end{tabular}

Table 1. Elemental composition of the different samples. 


\subsection{Extractions of biopolymers}

Several analytical methods are available for the determination of lignocellulosic components. We used 2 kinds of techniques: one for the determination of the plant composition (quantitative analysis) and the other for the extraction of native constituents of the fuel (qualitative analysis).

Lignocellulosic materials were determined by different gravimetric methods, according to normalized or published methods. Figure 1 shows the experimental procedure performed on every fuel.

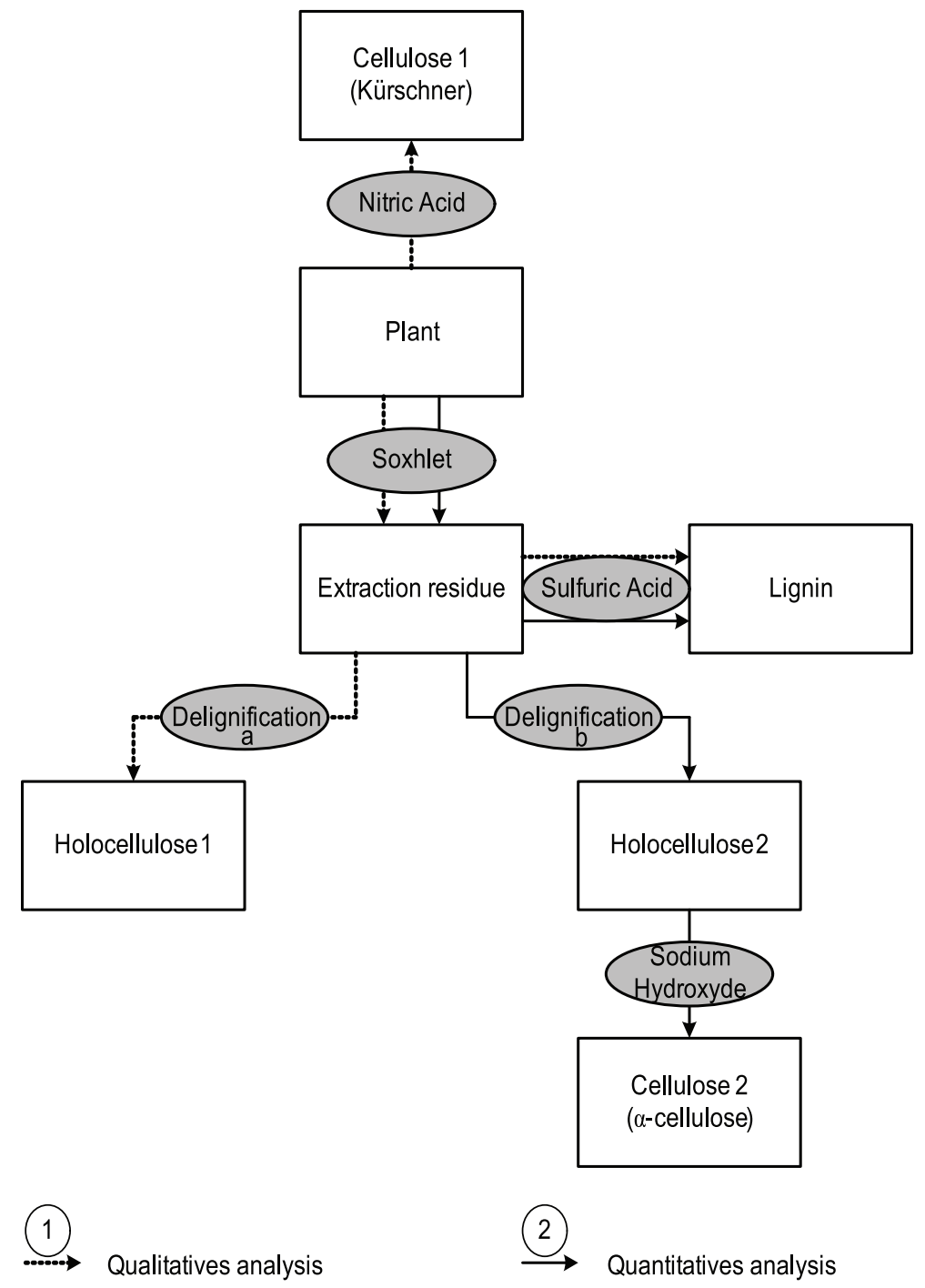

Fig. 1. Extractions diagram. 
The extraction methods are summarized below. The extraction process was a multi-stage one excepted for cellulose 1. First of all, the extractives were determined by Soxhlet extractions with dichloromethane for six hours. Then, the sample was washed with distilled water and oven-dried (Ona et al., 1994). From the extraction residue, we determined the lignin, the holocelluloses 1, 2 and the cellulose 2. The lignin "Klason" content was obtained by gravimetric analysis after a sulphuric acid attack (Tappi, 1974). Holocellulose (i.e cellulose + hemicellulose) content was also obtained by gravimetric analysis after reaction of the extraction residue with sodium chlorite in acetate buffer; this step is called delignification. The difference between delignification " $a$ " and " $b$ " comes from the concentrations of reagent used and time of stoking (Wise et al., 1946; Kaloustian et al., 1996). The action of hydroxyl sodium on holocelluose 2 allowed obtaining cellulose 2 . The cellulose 1 content was determined according to the Kürschner method (Peterssen, 1984; Kaloustian et al., 2003) directly on the powders by a gravimetric analysis after reaction with nitric acid.

As the chemical structure of hemicellulose and cellulose is very similar, there is no way to extract the native hemicellulose from the plant. That is why the proportions and the thermogram of this biopolymer were deducted from the difference between holocellulose and cellulose.

\subsection{Thermal analysis procedure}

There are only a few DSC studies in the literature concerning the thermal decomposition of lignocellulosic materials which is preferably studied by TGA (Bilbao et al., 1997; Branca \& Di Blasi, 2003; Safi et al., 2004; Liodakis et al., 2005; Pappa et al., 2006; Liodakis \& Kakardakis, 2008; Pappa et al. 2004). We recorded the emitted heat flow vs. temperature with a power compensated DSC (Perkin Elmer ${ }^{\circledR}$. Pyris ${ }^{\circledR} 1$ ). Thermal degradation was investigated in the range $400-900 \mathrm{~K}$ under dry air $(80 \% \mathrm{~N} 2 / 20 \% \mathrm{O} 2)$ with a gas flow of $30 \mathrm{ml} / \mathrm{min}$, measured at ambient temperature and atmospheric pressure.

We adapted the DSC for thermal degradation studies by adding an exhaust cover disposed on the measuring cell (degradation gases escape and pressure do not increase in the furnaces). The furnaces temperature was programmed for a linear heating from 400 to $900 \mathrm{~K}$ and we chose an intermediate heating rate $\beta=20 \mathrm{~K} / \mathrm{min}$ allowing very reproducible experiments. Open aluminium crucibles were used for both the sample and the reference (constituted of an empty crucible) (Tanaka, 1992). In every experiment, the powders were uniformly disposed on the bottom of the sample crucible. Samples consisted of about $5.0 \pm 0.1 \mathrm{mg}$ for all the experiments. The DSC calibration was performed at $20 \mathrm{~K} / \mathrm{min}$ and verified every 5 runs using the melting point reference temperature and enthalpy reference of pure indium and zinc (Tmelt $(\mathrm{In})=429.8 \mathrm{~K}$. $\Delta \mathrm{Hmelt}(\mathrm{In})=28.5 \mathrm{~J} / \mathrm{g}$. Tmelt $(\mathrm{Zn})=692.8 \mathrm{~K}$. $\Delta \mathrm{Hmelt}(\mathrm{Zn})=107.5 \mathrm{~J} / \mathrm{g})$. The four species and their components were thermally analysed according to this procedure. Data of interest were the enthalpy values obtained by numeric integration of the DSC signal and peak top temperatures visualised on the thermogram. The uncertainty caused by weighting gave an error of $2-3 \%$ on the experimental values of enthalpy reactions. The pc-DSC allowed the measurement of very repeatable heat flows thanks to the micro furnaces. The energy measured in those experiments corresponds to the oxidation of vegetative fuels in an open atmosphere, of course this are not the same values obtained with calorimetric bombs, but the study with an adapted pc-DSC (with the exhaust cover) is more representative of forest fire conditions. 


\section{Chemical analysis results}

All the results were expressed as a percentage on the dry matter (\%DM).

The amount of Soxhlet extract (Extracted Matter: EM) was calculated according to equation (1).

$$
\text { Extracted Matter }(\% D M)=\frac{\text { final sample mass }(g)}{\text { initial sample mass }(g)} \times 100
$$

Holocellulose content was calculated according to equation (2):

$$
\text { Holocellulose }(\% D M)=\left[\frac{\text { final sample mass }(g)}{\text { initial sample mass }(g)} \times \frac{100-E M}{100}\right] \times 100
$$

Where EM refers to the percentage of Extracted Matter.

Lignin content was obtained according to equation (3):

$$
\operatorname{Lignin}(\% D M)=\left[\frac{\text { final sample mass }(g)}{\text { initial sample mass }(g)} \times \frac{100-E M}{100}\right] \times 100
$$

Finally, cellulose 1 was given by (4):

$$
\text { Cellulose } 1(\% D M)=\frac{\text { final sample mass }(g)}{\text { initial sample mass }(g)} \times 100
$$

And cellulose 2 by (5):

$$
\text { Cellulose } 2(\% D M)=\left[\frac{\text { final sample mass }(g)}{\text { initial sample mass }(g)} \times \frac{\text { holocellulose }}{100}\right] \times 100
$$

Table 2 presents the results obtained from the analytical process and the previous equations for the species studied herein. The presented results are averages, calculated from several attempts on the same sample.

The measured total does not reach $100 \%$, because extractions are in series and there is a small amount of nitrogenous compounds, tannins and free sugars non extracted. For these fuels two dominants components were identified: lignin and cellulose.

\begin{tabular}{ccccccc}
\hline & $\begin{array}{c}\text { Cellulose } \\
(\%)\end{array}$ & $\begin{array}{c}\text { Lignin } \\
(\%)\end{array}$ & $\begin{array}{c}\text { Holo-cellulose } \\
(\%)\end{array}$ & $\begin{array}{c}\text { Hemi-cellulose } \\
(\%)\end{array}$ & $\begin{array}{c}\text { Extractive } \\
(\%)\end{array}$ & $\begin{array}{c}\text { Total } \\
(\%)\end{array}$ \\
\hline AU & $38.0 \pm 0.4$ & $41.6 \pm 0.4$ & $43.2 \pm 0.4$ & $5.2 \pm 0.1$ & $12.9 \pm 0.2$ & $97.9 \pm 1.0$ \\
EA & $40.7 \pm 0.4$ & $39.7 \pm 0.4$ & $54.3 \pm 0.5$ & $13.6 \pm 0.2$ & $5.8 \pm 0.1$ & $99.8 \pm 1.0$ \\
CM & $39.4 \pm 0.4$ & $34.4 \pm 0.3$ & $52.0 \pm 0.5$ & $12.6 \pm 0.2$ & $9.2 \pm 0.1$ & $95.6 \pm 1.0$ \\
PP & $38.3 \pm 0.4$ & $38.9 \pm 0.4$ & $43.4 \pm 0.4$ & $5.1 \pm 0.1$ & $13.1 \pm 0.2$ & $95.2 \pm 1.0$ \\
\hline
\end{tabular}

Table 2. Composition of the different samples 


\section{Thermal analysis results}

The results from the thermal analysis of the four species and their components are shown in the present section; we chose to present only the curves of CM samples. This plant is known to have a high flammability in wildland fires.

\subsection{Vegetation}

Table 3 presents the reaction enthalpy and the peak top temperatures obtained from the DSC data on every fuel. Values of enthalpies are expressed for one gram of the fuel used for each experiment.

\begin{tabular}{cccc}
\hline & $\Delta_{\mathrm{r}} \mathrm{H}^{\circ}(\mathrm{J} / \mathrm{g})$ & Peak 1 (K) & Peak 2 (K) \\
\hline $\mathrm{AU}$ & $-11410 \pm 342$ & 641 & 791 \\
$\mathrm{EA}$ & $-12540 \pm 376$ & 646 & 787 \\
$\mathrm{CM}$ & $-11070 \pm 332$ & 630 & 776 \\
$\mathrm{PP}$ & $-10885 \pm 327$ & 643 & 756 \\
\hline
\end{tabular}

Table 3. Enthalpy value and peak top temperature of the different samples.

The enthalpy reaction (numeric integration of DSC signal) is varying between -10885J/g to $12540 \mathrm{~J} / \mathrm{g}$ for these different fuels. EA fuel was found to be the most energetic one and PP fuel was found to be the less energetic one. As the sample preparation and the experimental conditions were constant for all the fuels, the differences observed on the enthalpy values should come from the chemical composition of each fuel.

Figure 2 shows the thermal behavior of CM sample. For all the fuels the DSC curves exhibit a similar profile with two overlapped exothermic events. Two maxima were recorded around $630 \mathrm{~K}$ and $775 \mathrm{~K}$; in a previous work we ascribed these thermal events (Cancellieri et al., 2005) corresponding to the oxidation of volatiles and chars. The behavior is similar and reproducible for all the species since we have triplicate experiments for all the species.

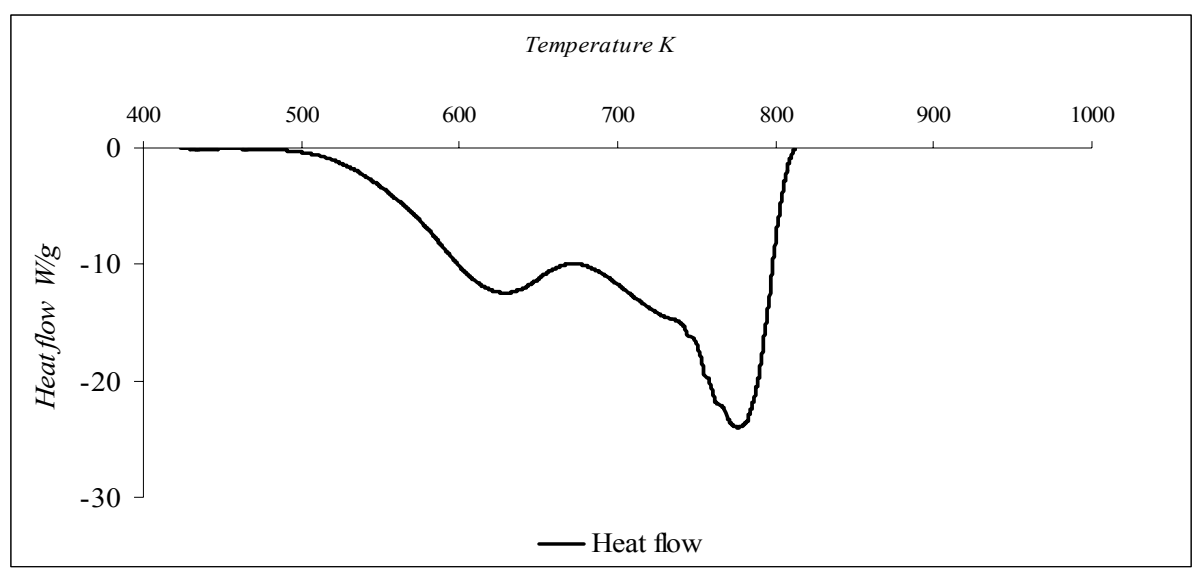

Fig. 2. DSC curve for $\mathrm{CM}$ at $20 \mathrm{~K} / \mathrm{min}$ under air sweeping. 


\subsection{Extracted cellulose}

Following the extraction, the cellulose from each fuel was thermally studied and table 4 presents the results obtained from the DSC data. Values of enthalpies are expressed for one gram of the cellulose used for each experiment.

It is important to note the strong resemblances of the thermal characteristics of the cellulose extracted from the various species. The values of enthalpy of the thermal degradation of cellulose are relatively constant for four plants (mean value: $\Delta \mathrm{rH}^{\circ}=-6892 \pm 213 \mathrm{~J} / \mathrm{g}$ ) assuming that the cellulose extracted from these plants possesses a very close structure. Ours experiments show that cellulose is the lowest energetic component of the fuels.

\begin{tabular}{cccc}
\hline & $\Delta \mathrm{H}_{\text {exp }}(\mathrm{J} / \mathrm{g})$ & $\mathrm{T}_{\text {exo }} 1(\mathrm{~K})$ & $\mathrm{T}_{\text {exo }} 2(\mathrm{~K})$ \\
\hline $\mathrm{AU}$ & $-6935 \pm 208$ & 623 & 766 \\
$\mathrm{EA}$ & $-7179 \pm 215$ & 627 & 803 \\
$\mathrm{CM}$ & $-6581 \pm 197$ & 623 & 778 \\
$\mathrm{PP}$ & $-6871 \pm 206$ & 628 & 799 \\
\hline
\end{tabular}

Table 4. Enthalpy value and peak top temperature of extracted cellulose.

Figure 3 shows the thermal behavior of CM cellulose:

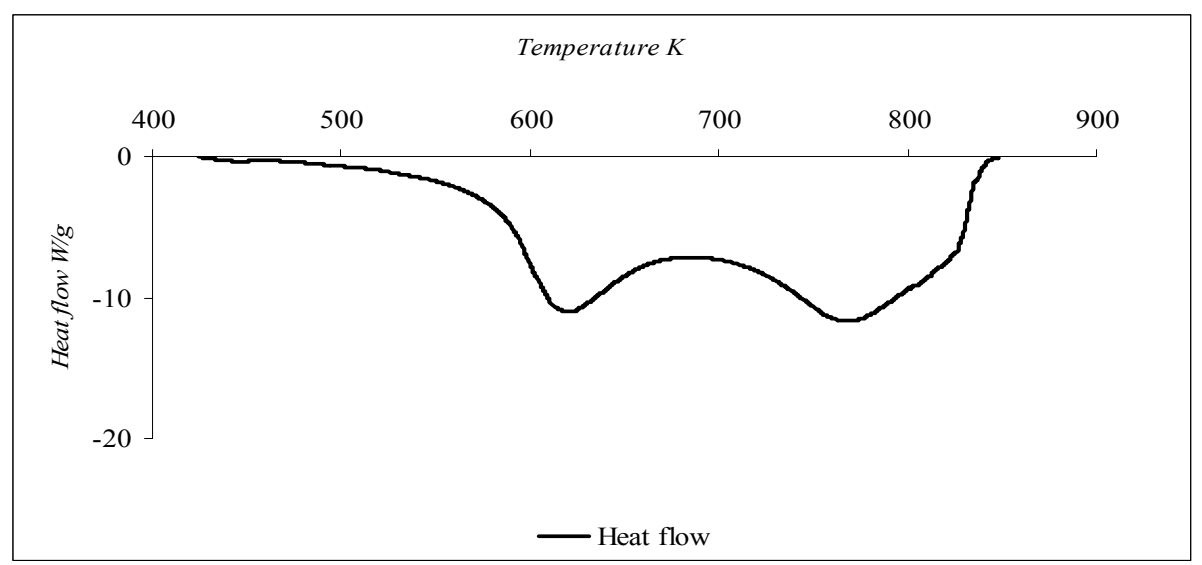

Fig. 3. DSC curve for CM cellulose at $20 \mathrm{~K} / \mathrm{min}$ under air sweeping.

For all the fuels the DSC curves exhibit a similar profile with two overlapped exothermic events, the thermal behaviour of the cellulose extracted from the various species is similar to that of fuel. However, existing energetic interactions between the components are shown by comparing the curves of the fuel and the cellulose: the offset temperature is higher for the cellulose. In the modeling work we have neglected these interactions.

\subsection{Extracted holocellulose}

Following the extraction, the holocellulose from each fuel was thermally studied and table 5 presents the results obtained from the DSC data. Values of enthalpies are expressed for one gram of the holocellulose used for each experiment. 
Values of enthalpies are globally higher for the holocellulose than the cellulose; this component can be considered as highly energetic in regard to the fuels. We noted a global trend similar to that of the plant, except the appearance of a supplementary phenomenon (peak 2') between both processes already shown on the fuels. This additional step is probably coming from the thermal degradation of hemicellulose mixed with cellulose in this component; unfortunately, we did not have the possibility to isolate hemicellulose from holocellulose. Figure 4 shows the thermal behavior of CM holocellulose obtained following the previously described method.

\begin{tabular}{ccccc}
\hline & $\Delta_{\mathrm{r}} \mathrm{H}^{\circ}(\mathrm{J} / \mathrm{g})$ & Peak 1 $(\mathrm{K})$ & Peak 2' $^{\prime}(\mathrm{K})$ & Peak 2 $(\mathrm{K})$ \\
\hline AU & $-10565 \pm 317$ & 626 & 687 & 786 \\
EA & $-10891 \pm 327$ & 609 & 687 & 759 \\
$\mathrm{CM}$ & $-8974 \pm 269$ & 615 & 684 & 767 \\
PP & $-9789 \pm 294$ & 625 & 697 & 754 \\
\hline
\end{tabular}

Table 5. Enthalpy value and peak top temperature of extracted holocellulose.

Figure 4 shows the thermal behavior of CM holocellulose obtained following the previously described method.

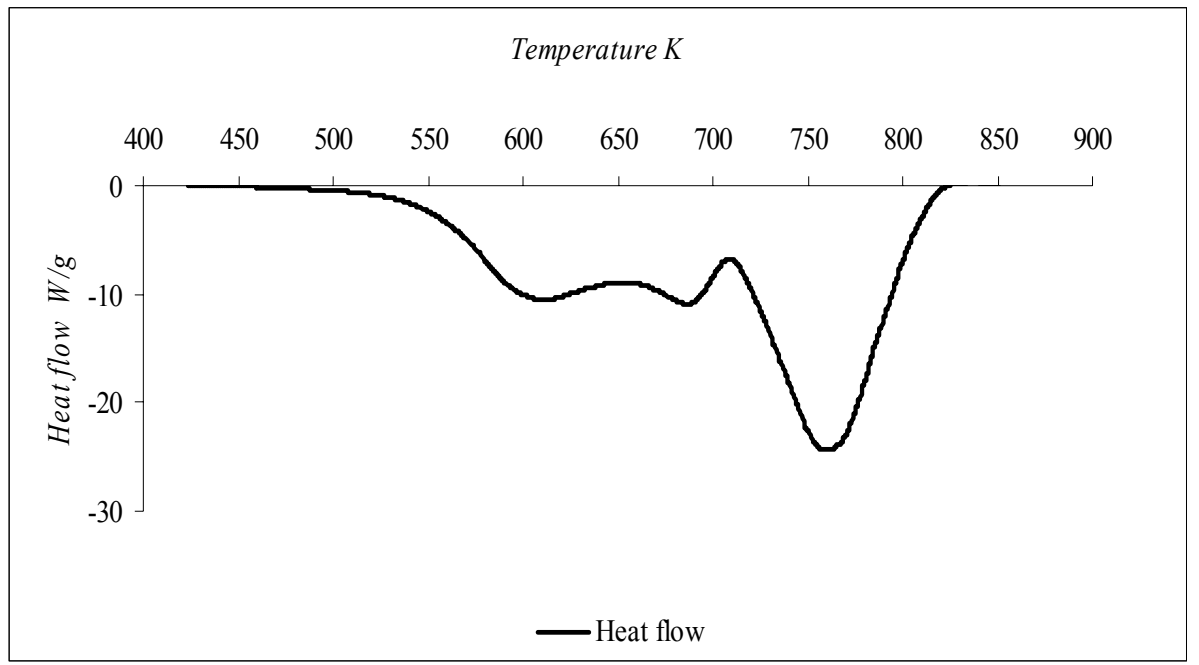

Fig. 4. DSC curve for CM holocellulose at $20 \mathrm{~K} / \mathrm{min}$ under air sweeping.

This biopolymer showed a degradation process more complex than the other constituents. These observations are coherent as the holocellulose is a mixture of polysaccharides.

\subsection{Extracted lignin}

Following the extraction, the lignin from each fuel was thermally studied and table 6 presents the results obtained from the DSC data. Values of enthalpies are expressed for one gram of the lignin used for each experiment. 
For all the species, we recorded a more marked difference between extracted lignin and the fuel. In regard with others biopolymers the value of reaction enthalpy is much higher and the major part of the exotherm is shifted toward high temperatures. Lignin is the highest energetic component of the fuel with a mean value of reaction enthalpy higher than the fuel itself.

\begin{tabular}{cccc}
\hline & $\Delta_{\mathrm{r}} \mathrm{H}^{\circ}(\mathrm{J} / \mathrm{g})$ & Peak 1 $(\mathrm{K})$ & Peak 2 $(\mathrm{K})$ \\
\hline $\mathrm{AU}$ & $-16278 \pm 488$ & 653 & 846 \\
$\mathrm{EA}$ & $-16853 \pm 505$ & 668 & 831 \\
$\mathrm{CM}$ & $-15172 \pm 455$ & 662 & 815 \\
$\mathrm{PP}$ & $-17012 \pm 510$ & 682 & 799 \\
\hline
\end{tabular}

Table 6. Enthalpy value and peak top temperature of extracted lignin.

As shown on the example of figure 5, DSC curves present an important amplitude for the peak 2 and a peak 1 almost flooded by the second. As for the cellulose, lignin curves shows existing energetic interactions between the components. Comparing the curves of the fuel and the cellulose we saw that the temperature of the end of reaction is higher for the lignin. In the modeling work we have neglected these interactions.

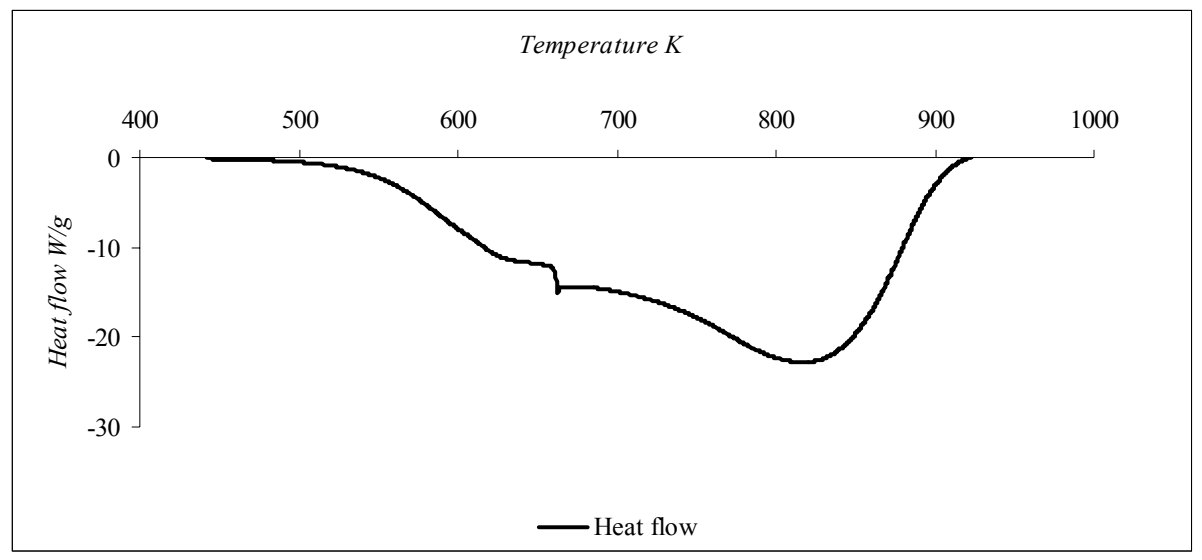

Fig. 5. DSC curve for CM lignin at $20 \mathrm{~K} / \mathrm{min}$ under air sweeping.

All the thermograms also present an artefact owed to a condensation of products during the acidic extraction of lignin. This thermal behaviour agrees with previous studies (tsujiyama \& Miyamori, 2000) indicating an only important peak for temperatures superior to $773 \mathrm{~K}$.

\section{Modelling}

Mean values of reaction enthalpies are presented in the following table 7 and were calculated from the data presented in tables 4,5 and 6 . The standard deviation was determined according to equation 6 . 


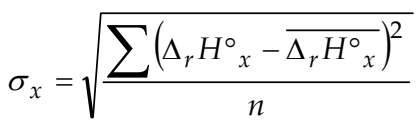

where $\overline{\Delta_{r} H^{\circ}}$ is average of $\Delta_{r} H^{\circ}, x$ is a component and $n$ is the number of values.

\begin{tabular}{ccccc}
\hline & Cellulose & Lignin & Hemicellulose & Extractives \\
\hline$\overline{\Delta_{r} H^{\circ}}(\mathrm{J} / \mathrm{g})$ & -6892 & -16329 & -15109 & -8176 \\
\hline$\sigma$ & 245,9 & 833,1 & 1318,7 & 2031,0 \\
\hline$\frac{\sigma}{\overline{\Delta_{r} H^{\circ}}} \times 100$ & $3,6 \%$ & $5,1 \%$ & $8,9 \%$ & $24,8 \%$ \\
\hline
\end{tabular}

Table 7. Mean values of enthalpy reaction of the components in the 4 species.

The enthalpy variations of the various constituents are relatively constant and close to mean values. The relative error for every constituent is lower than $9 \%$, except for the extractives $(25 \%)$ which constitute a complex mixture of various chemicals. This result is however coherent, as far as the nature of compounds contained in the extracted matters varies according to the species (wax quantities, tannins, essential oil and colouring agents differ strongly according to the species).

According to assumption presented in the introduction section, in this work the thermal degradation of forest fuels is viewed as the thermal degradation of the components of the fuel as shown in figure 6.

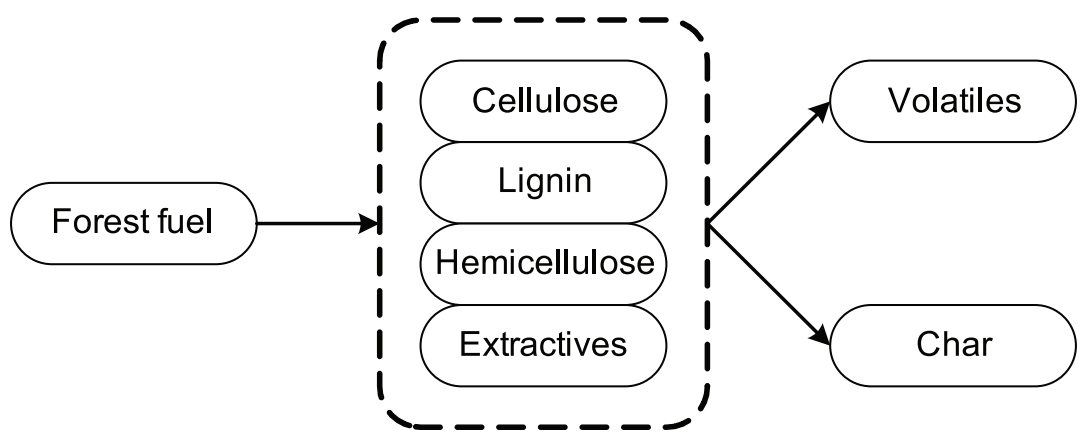

Fig. 6. Schematic thermal degradation of a forest fuel.

Compared to others studies, (Koufopanos et al., 1989; Kohler et al., 2005; Miller \& Bellan, 1997; Caballero et al., 1996) we added the thermal behaviour of the extractives components which play an important role in wildland fires spread (Oasmaa et al., 2003a; Oasmaa et al., 2003b; Pappa et al., 2000).

The calculated reaction enthalpy can then be expressed as a combination of reaction enthalpy of each component of the fuel: 


$$
\begin{gathered}
\Delta \mathrm{rH}^{\circ}{ }_{\text {Mod }}=\mathrm{a} \Delta \mathrm{rH}^{\circ}{ }_{\text {(cellulose) }}+\mathrm{b} \Delta \mathrm{rH}^{\circ}{ }_{\text {(lignin) }}+ \\
\mathrm{c} \Delta \mathrm{rH}^{\circ}{ }_{\text {(hemicellulose) }}+\mathrm{d} \Delta \mathrm{rH}^{\circ}{ }_{\text {(extractives) }}
\end{gathered}
$$

where: $a, b, c$ and $d$ are the percentages of cellulose, lignin, hemicellulose and extractives respectively in the fuel.

This model is applicable and sturdy only if the enthalpy reaction of every constituent is constant for all the species. We thus made the following hypotheses of modelling which are valid in regard to the experimental results presented in table 7.

$$
\begin{aligned}
& \Delta \mathrm{rH}^{\circ}{ }_{(\text {cellulose) } \mathrm{EA}} \approx \Delta \mathrm{rH}^{\circ}{ }_{\text {(cellulose) } \mathrm{AU}} \approx \Delta \mathrm{rH}^{\circ}{ }_{\text {(cellulose }) \mathrm{CM}} \approx \\
& \Delta \mathrm{rH}^{\circ}{ }_{\text {(cellulose)PP. }} \\
& \Delta \mathrm{rH}_{(\text {lignin) } \mathrm{EA}}^{\circ} \approx \Delta \mathrm{rH}_{(\text {lignin) } \mathrm{AU}}^{\circ} \approx \Delta \mathrm{rH}_{(\text {lignin }) \mathrm{CM}}^{\circ} \approx \\
& \Delta \mathrm{rH}^{\circ}{ }_{(\text {lignin)PP. }} \\
& \Delta \mathrm{rH}_{\text {(hemi.) } \mathrm{EA}} \approx \Delta \mathrm{rH}^{\circ}{ }_{\text {(hemi.) } \mathrm{AU}} \approx \Delta \mathrm{rH}^{\circ}{ }_{\text {(hemi.) } \mathrm{CM}} \approx \\
& \Delta \mathrm{rH}^{\circ}{ }_{\text {(hemi.)PP. }}
\end{aligned}
$$

However it was impossible to study the thermal behaviour of extractives (too unstable and giving very noisy DSC curves). Their enthalpy reaction was deducted by subtraction between the enthalpy reaction of the fuel and the enthalpy reaction of the residue from the solvent extraction. We thus made the following assumption:

$$
\begin{array}{r}
\Delta \mathrm{rH}^{\circ}{ }_{(\text {extra. }) \mathrm{EA}} \approx \Delta \mathrm{rH}^{\circ}{ }_{(\text {extra. }) \mathrm{AU}} \approx \Delta \mathrm{rH}^{\circ}{ }_{(\text {extra. }) \mathrm{CM}} \approx \\
\Delta \mathrm{rH}^{\circ}{ }_{(\text {extra. }) \mathrm{PP} .}
\end{array}
$$

Equation 7 gave allowed the calculation of modelled enthalpies $\left(\Delta \mathrm{rH}^{\circ}{ }_{\text {Mod }}\right)$ for the four species according to their chemical composition.

Figure 7 shows the experimental enthalpy $\left(\Delta \mathrm{rH}^{\circ} \exp \right)$ of thermal degradation of the fuels versus the results of calculated enthalpy. This figure clearly shows that according to its high enthalpy of reaction and its high content in the four species, lignin contributes strongly to the reaction enthalpy of the fuel. Compared to lignin, the low value of enthalpy of reaction of cellulose implies a weak contribution to the reaction enthalpy of the fuel for this component though cellulose content is as important as lignin. Our model takes into account the extractives percentage in the fuel; even if their content is low, these components are highly energetic and they should not be omitted in regard to the thermal behaviour of the fuels.

As shown in figure 7, the calculated enthalpy values get very close to the experimental values recorded from the thermal degradation of dry forest fuels.

The small difference between the model and experiments results indicates that energetic interactions between the various constituents of the plant can be neglected.

Regarding to the fuels: EA fuel was found to be the most energetic with the higher hemicellulose content and the lowest extractives content whereas PP fuel was found to be the less energetic fuel with the lowest hemicellulose content and the higher extractives content.

This approach is interesting since the reaction enthalpy of the thermal degradation can be calculated with the knowledge of the composition of the fuel. The reaction enthalpy of the thermal degradation is an important data in the field wildland fire modelling. In a future work we will study others fuels with a final objective to get an energetic profile of the forest fuels according to their chemical composition. 


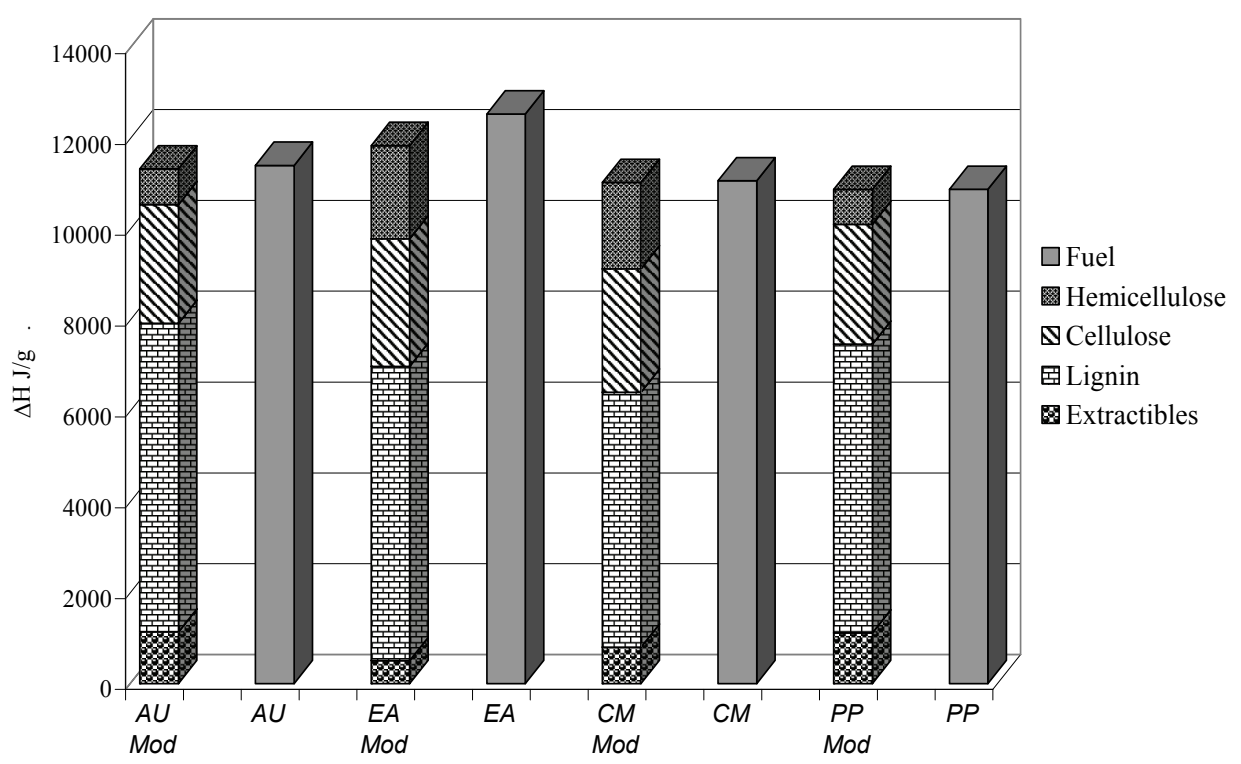

Fig. 7. Comparison between modelled and experimental enthalpy.

\section{Conclusion}

In wildland fire modelling and forest fuel hazard studies, the thermal degradation of the solid is a fundamental stage. Two ways are suitable: the first one considers the thermal degradation of the whole fuel giving a complex mixture of gas, tars and chars; the second one considers the thermal degradation as the sum of the contributions from the principal components of the fuel. Our aim was to verify the validity of the second approach. DSC analyses were performed in order to get the enthalpy reaction of the thermal degradation under air for four forest fuels and their components. With the assumption of constant enthalpies values for each component, we calculated the enthalpy reaction of the thermal degradation.

Calculated enthalpy was compared to the experimental data and we showed a good agreement. Thus, we can say that the reaction enthalpy of the fuels can be viewed as the sum of the reaction enthalpy of each component (taking into account their percentages in the fuel). The present study shows only a weak influence of interactions between the components in the fuel on the reaction enthalpy of thermal degradation.

This approach seems very interesting in order to get the enthalpy reaction of a forest fuel when its composition is available. This data is important for modelling purpose since the rate of consumption of fuels could be calculated from the energy emitted by gram of fuel when the power of the fire is available. Although this approach is attractive by its simplicity, the attempt to reproduce the complete thermal behaviour of a fuel turns out to be a delicate spot at the moment. 


\section{References}

Alèn, R.; Kuoppala, E.; Oesch, P.J. (1996) Formation of the main degradation compound groups from wood and its components during pyrolysis. J. Anal. Appl. Pyrolysis, Vol.36, 137-148, 0165-2370.

Andrews, P.L. (1986) Behave: Fire behaviour prediction and fuel modelling system Burn subsystem. Part I. USDA Forest Service Research, Paper INT-194, 03636259.

Balbi, J.H.; Santoni, P.A.; Dupuy, J.L. (2000) Dynamic modelling of fire spread across a fuel bed. Int. J. Wildland Fire, Vol.9, 275-284, 1049-8001.

Beall, F.C.; Eickner, H.W. (1970) Thermal degradation of wood components: a review of literature, Forest Service Research, Paper FPL 130, 0363-6259.

Bilbao, R.; Mastral, J.F.; Aldea, M.E.; Ceamanos, J. (1997) The influence of the percentage of oxygen in the atmosphere on the thermal degradation of lignocellulosic materials, J. Anal. Appl. Pyr.,, Vol.42, 189-202,0165-2370.

Branca, C.; Di Blasi, C. (2003) Kinetics of the isothermal degradation of wood in the temperature range 528-708K, J. Anal. Appl. Pyr., Vol.67, 207-219, $0165-2370$.

Burrows, N.D. (2001) Flame residence times and rates of weight loss of eucalypt forest fuel particles. Int. J. Wildland Fire, Vol.10, 137-143, 1049-8001.

Caballero, J.A.; Font, R.; Marcilla; A. (1996) Comparative study of the pyrolysis of almond shells and their fractions, holocellulose and lignin. Product yields and kinetics. Thermochim. Acta, Vol.276, 57-77, 0040-6031.

Cancellieri, D.; Leoni, E.; Rossi, J.L. (2005) Kinetics of the Thermal Degradation of Erica Arborea by DSC: Hybrid Kinetic Method. Thermochim. Acta, Vol.438, 41-50, 00406031.

Cozzani, V.; Lucchesi, A.; Stoppato, G. (1997) A new method to determine the composition of biomass by thermogravimetric analysis. The Cana. J. Chem. Eng., Vol.75, 127133, 0008-4034.

De Luis, M.; Baeza, M.J.; Raventos, J. (2004) Fuel characteristics and fire behaviour in mature Mediterranean gorse shrublands. Int. J. Wildland Fire, Vol.13, 79-87, 10498001.

Dimitrakopoulos, A.P. (2001) Thermogravimetric analysis of Mediterranean plant species. J. Anal. Appl. Pyrolysis, Vol.60, 123-130, 0165-2370.

Grishin, A.M.; Gruzin, A.D.; Zverev, V.G. (1983) Matematical modelling of the spreading of hight level forest fires. Sov.phys.Dokl., Vol.28, 328-330, 0038-5689.

Kaloustian, J.; Pauli, A.M.; Pastor, J. (1996) Etude par analyse thermique de quelques végétaux méditerranéens, J. Therm. Anal. Cal.,, Vol.46, 1388-6150.

Kaloustian, J.; El-Moselhy, T.F.; Portugal, H. (2003) Chemical and thermal analysis of the biopolymers in thyme, Thermochim. Acta, Vol.401, 77-86, 0040-6031.

Kohler, S.; Mauviel, G.; Ferrer, M; Lédé, J. (2005) Flash pyrolysis of biomass model components and of their mixtures. 14th European Biomass Conference and Exhibition , Paris, Octobre 2005, Biomass for Energy, Industry and Climate Protection, Paris. 
Koufopanos, C.A.; Maschio, G.; Lucchessi, A. (1989) Kinetics modelling of the pyrolysis of biomass and biomass components. The Can. J. Chem. Eng., Vol.67, 75-84, 00084034 .

Larini, M.; Giroux, F.; Porterie, B.; Loraud, J.C. (1997) A multiphase formulation for fire propagation in heterogeneous various analytical methods. Int. J. Heat and Mass Transfer, Vol.41, 881-897, 0017-9310.

Leoni, E.; Cancellieri, D.; Balbi, N.; Tomi, P.; Bernardini, A.F.; Kaloustian, J.; Marcelli, T. (2003) Thermal degradation of Pinus pinaster Needles by DSC, Part 2: Kinetics of Exothermic phenomena. J. Fire Sciences, Vol.21, 117-130, 07349041.

Linn, R.R.; Cunningham, P. (2005) Numerical simulations of grass fires using a coupled atmosphere fire model: Basic fire behavior and dependence on wind speed. Journal of Geophysical Research, Vol.110, 1-19, 0148-0227.

Liodakis, S.; Bakirtzis, D.; Dimitrakopoulos, A.P. (2002) Ignition characteristics of forest species in relation to thermal analysis data. Thermochim. Acta, Vol.390, 83-91, 00406031.

Liodakis, S.; Katsigiannis, G.; Kakali, G. (2005) Ash properties of some dominant Greek forest species. Thermochim. Acta, Vol.437, 158-167, 0040-6031.

Liodakis, S.; Kakardakis, T. (2008) Measuring the relative particle foliar combustibility of WUI forest species located near Athens. J. Therm. Anal. Cal., Vol.93, 627-635, 13886150 .

Miller, R.S.; Bellan, J. (1997) A generalized biomass pyrolysis model based on superimposed cellulose, hemicellulose and lignin kinetics. Combustion Science and Technology, Vol.126, 97-137, 0010-2202.

Morvan, D.; Dupuy, J.L. (2004) Modeling the propagation of a wildfire through a Mediterranean shrub using a multiphase formulation, Combustion and flame, Vol.138, 199-210, 0010-2180.

Morvan, D. (2005) Physique et modélisation du comportement des feux de forêt. 17ème Congrès Français de Mécanique, Plenary conference August 2005, Troyes, France.

Núnez-Regueira, L.; Rodríguez-Anón, J.A.; Proupín, J.; Mourino, B.; Artiaga-Diaz R. (2005) Energetic study of residual forest biomass using calorimetry and thermal analysis. J. Therm. Anal. Cal., Vol.80, 457-464, 1388-6150.

Oasmaa, A.; Kuoppala, E.; Gust, S.; Solantausta, Y. (2003) Fast Pyrolysis of Forestry Residue. 1. Effect of Extractives on Phase Separation of Pyrolysis Liquids. Energy \& Fuels, Vol.17, 1-12, 0887-0624.

Oasmaa, A.; Kuoppala, E.; Solantausta, Y. (2003) Fast Pyrolysis of Forestry Residue. 2. Physicochemical Composition of Product Liquid. Energy \& Fuels, Vol.17, 433-443, 0887-0624.

Ona, T.; Testsuya, S.; Masaru, S.; Kazumi, F. (1994) Small-scale method to determine the content of wood components from multiple eucalypt samples. Tappi journal, Vol.78, No 3, 121-126, 0734-1415. 
Órfão, J.J.M.; Antunes, F.G.A.; Figueiredo, J.L. (1999) Pyrolysis kinetics of lignocellulosic materials - three independent reactions model. Fuel, Vol.78, 349-346, 0016-2361.

Pappa, A.; Tzamtzis, N.; Statheropoulos, M.; Fasseas, C. (2000) The pyrolytic behavior of Pinus halepensis needles observed by transmission light microscopy and stereoscopy. J. Anal. Appl. Pyr., 55, 195-202, 0165-2370.

Pappa, A.; Mikedi, K.; Tzamtzis, N. Statheropoulos, M. (2006) TG-MS analysis for studying the effects of fire retardants on the pyrolysis of pine-needles and their components. J. Therm. Anal. Cal., Vol.84, 655-661, 1388-6150.

Pappa, A.; Kyriakou, S.; Mikedi, K.; Tzamtzis, N.; Statheropoulos, M. (2004) Design considerations and an example of application of an in-house made TG-MS interface. J. Therm. Anal. Cal., Vol.78, 415-426, 1388-6150.

Petterssen, R.C.; (1984) Chemical composition of wood. Chapter 2. The Chemistry of Solid. R.R. Wood (Ed.), Advances in Chemistry Series 207, American Chemical Society, Washington, DC.

Rothermel, R.C. (1983) How to predict the spread and intensity of forest and range fires. USDA Forest Service Research, Paper INT-143, 0363-6259.

Safi, M.J.; Mishra, I.M.; Prasad, B. (2004) Global degradation kinetics of pine needles in air, Thermochim. Acta, Vol.412, 155-162, 0040-6031.

Sero-Guillaume, O; Margerit, J. (2002) Modelling forest fires. Part I: a complete set of equations derived by extended irreversible thermodynamics, Int. J. Heat and Mass Transfert, Vol.45, 1705-1722, 0017-9310.

Shanmukharadhya, K. S.; Sudhakar K. G. (2007) Experimental investigations for the location of reaction zones in a bagasse fired furnace. J. Therm. Anal. Cal., Vol.90, 299-306, 1388-6150.

Simeoni, A.; Santoni, P.A.; Larini, M.; Balbi, J.H. (2001) Proposal for theoretical contribution for improvement of semi-physical forest fire spread models thanks to a multiphase approach: application to a fire spread model across a fuel bed. Combustion Science and Technology, Vol.162, 59-84, 0010-2202.

Stenseng, M.; Zolin, A.; Cenni, R.; Frandsen, F.; Jensen, A; Dam-Johansen, K. (2001) Thermal Analysis in Combustion Research. J. Therm. Anal. Cal., Vol.64, 1325-1354, 13886150.

Tanaka, S. (1992) Theory of power-compensated DSC, Thermochim. Acta, Vol.210, 67-76, 0040-6031.

Tappi,(1974) Acid insoluble lignin in wood and pulp. rapport T 222 05-74.

Tonbul, Y. (2008) Pyrolysis of pistachio shell as a biomass. J. Therm. Anal. Cal., Vol.91, 641$647,1388-6150$.

Tsujiyama, S.I.; Miyamori, A. (2000) Assignment of DSC thermograms of wood its components, Thermochim. Acta, Vol.351, 177-181, 0040-6031.

Weiland, J.J. ; Guyonnet, R.; Gibert, R. (1998) Analyse de la pyrolyse ménagée du bois par couplage TG-DSC-IRTF. J.Therm. Anal., Vol.51, 265-274, 1388-6150.

Wise, L.E.; Murphy, M.; D'Addieco, A.A. (1946) Chlorite holocellulose, its fractionation and bearning on sommative wood analysis and on studies on the hemicelluloses, Tappi Paper Trade Journal, Vol.122, 11-19, 0031-8655. 
Yuan, H.R.; Liu R.H. (2007) Study on pyrolysis kinetics of walnut shell. J. Therm. Anal. Cal. , Vol.89, 983-986, 1388-6150. 


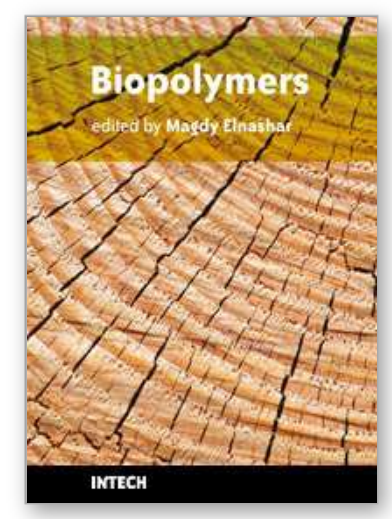

\author{
Biopolymers \\ Edited by Magdy Elnashar
}

ISBN 978-953-307-109-1

Hard cover, 612 pages

Publisher Sciyo

Published online 28, September, 2010

Published in print edition September, 2010

Biopolymers are polymers produced by living organisms. Cellulose, starch, chitin, proteins, peptides, DNA and RNA are all examples of biopolymers. This book comprehensively reviews and compiles information on biopolymers in 30 chapters. The book covers occurrence, synthesis, isolation and production, properties and applications, modification, and the relevant analysis methods to reveal the structures and properties of some biopolymers. This book will hopefully be of help to many scientists, physicians, pharmacists, engineers and other experts in a variety of disciplines, both academic and industrial. It may not only support research and development, but be suitable for teaching as well.

\title{
How to reference
}

In order to correctly reference this scholarly work, feel free to copy and paste the following:

Valérie Leroy, Eric Leoni and Dominique Cancellieri (2010). Thermal Degradation of Lignocellulosic Fuels: Biopolymers Contribution, Biopolymers, Magdy Elnashar (Ed.), ISBN: 978-953-307-109-1, InTech, Available from: http://www.intechopen.com/books/biopolymers/thermal-degradation-of-lignocellulosic-fuels-biopolymerscontribution-

\section{INTECH}

open science | open minds

\section{InTech Europe}

University Campus STeP Ri Slavka Krautzeka 83/A 51000 Rijeka, Croatia Phone: +385 (51) 770447

Fax: +385 (51) 686166 www.intechopen.com

\section{InTech China}

Unit 405, Office Block, Hotel Equatorial Shanghai No.65, Yan An Road (West), Shanghai, 200040, China 中国上海市延安西路65号上海国际贵都大饭店办公楼405单元 Phone: +86-21-62489820

Fax: +86-21-62489821 
(C) 2010 The Author(s). Licensee IntechOpen. This chapter is distributed under the terms of the Creative Commons Attribution-NonCommercialShareAlike-3.0 License, which permits use, distribution and reproduction for non-commercial purposes, provided the original is properly cited and derivative works building on this content are distributed under the same license. 